\title{
Two new species in the Matelea stenopetala complex (Apocynaceae, Asclepiadoideae) from the Guiana Shield and Amazonian Brazil
}

\author{
Alexander Krings', Gilberto Morillo² \\ I Herbarium, Department of Plant Biology, North Carolina State University, Raleigh, NC 27695-7612, USA \\ 2 Herbario Carlos Liscano, Facultad de Ciencias Forestales y Ambientales, Universidad de Los Andes, Mérida \\ 5101-A, Venezuela
}

Corresponding author: Alexander Krings (Alexander_Krings@ncsu.edu)

Academic editor: Lena Struwe | Received 7 June 2012 | Accepted 19 September 2012 | Published 26 September 2012

Citation: Krings A, Morillo G (2012) Two new species in the Matelea stenopetala complex (Apocynaceae, Asclepiadoideae) from the Guiana Shield and Amazonian Brazil. PhytoKeys 17: 27-39. doi: 10.3897/phytokeys.17.3485

\begin{abstract}
Two new species in the Matelea stenopetala complex (Apocynaceae, Asclepiadoideae) are described from the Guiana Shield and Amazonian Brazil: Matelea brevistipitata Krings \& Morillo, sp. nov. and $M$. trichopedicellata Krings \& Morillo, sp. nov. The new species belong to a small group of adaxially-pubescent-flowered taxa within the complex, including $M$. hildegardiana and $M$. pakaraimensis. The new species are described and a dichotomous key is provided.
\end{abstract}

\section{Keywords}

Gonolobinae, Matelea, Neotropics, twining vines, taxonomy

\section{Introduction}

The Matelea stenopetala Sandwith complex (Apocynaceae, Asclepiadoideae, Gonolobinae) in northern South America includes about ten species of vines (Morillo 1988, 1991; Farinaccio and Stevens 2009; Krings 2011). Members of the complex are recognized by leaves membranous, often more or less elliptic or oblong and relatively large (to ca. 17 x $8 \mathrm{~cm}$ ), leaf bases frequently narrow and cuneate or acute, flowers small (corolla lobes usually $\leq$ 4-5 $\mathrm{mm}$ long [to $5.8 \mathrm{~mm}$ in $M$. cayennensis Morillo]), typically green to greenish-yellow, reticulate but not ocellate, and gynostegial coronas not elaborate, the staminal corona segments (Cs) usually appearing as ridges emanating from the central stipe and the interstaminal corona segments (Ci) appearing as sinuses in between the Cs. The morphology 
of the flowers is strikingly similar to Matelea palustris Aubl. [type of Matelea Aubl.], the affinity to which has been pointed out by Sandwith (1931: his protologue of M. stenopetala), as well as by Farinaccio and Stevens (2009). On-going work for various regional initiatives, including the Flora of the Guianas and the Biological Diversity of the Guiana Shield, has resulted in the discovery of two new species referable to the $M$. stenopetala complex. Both new species exhibit corolla lobes adaxially pubescent, a character state shared in the complex only by $M$. hildegardiana Morillo (Venezuela), M. pakaraimensis Krings (Guyana), and, very rarely, M. stenopetala (northern South America). The new species are described and distinguished below. Corona morphological terminology follows Liede and Kunze (1993), although it is recognized that additional work may be needed to clarify issues of family-wide homology (see Endress and Bruyns 2000, Livshultz 2003). Shorthand abbreviations for corona morphology following Liede and Kunze (1993) are as follows: $\mathrm{Ca}=$ annular corona of corolline derivation (faucal annulus); $\mathrm{Ci}=$ interstaminal corona; $\mathrm{C}(\mathrm{is})=$ fused interstaminal and staminal corona; $\mathrm{Cs}=$ staminal corona.

\section{Data resources}

The data underpinning the analysis reported in this paper are deposited at GBIF, the Global Biodiversity Information Facility, http://ipt.pensoft.net/ipt/resource.

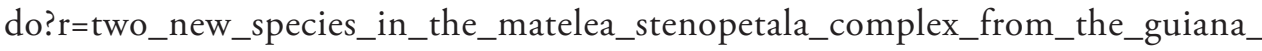
shield_and_amazonian_brazil

\section{Taxonomic treatment}

\section{Key to the adaxially-pubescent-flowered members of the Matelea sten- opetala complex}

1 Abaxial corolla surface conspicuously pubescent, trichomes predominantly eglandular, glandular capitate trichomes absent or sparse and inconspicuous.... 2

- $\quad$ Abaxial corolla surface glabrous or minutely and indistinctly pubescent, trichomes primarily glandular capitate, eglandular trichomes absent or rare ...3

2 Leaf bases broadly cuneate to rounded; pedicels with only glandular capitate trichomes ubiquitous, eglandular trichomes not ubiquitous, instead in two lines, ca. $0.3 \mathrm{~mm}$ long; corolla rose, lobes $4.1-4.2 \mathrm{~mm}$ long; Figs. 1A, 2A, 3A, $4 \mathrm{~B}, 6$

Matelea trichopedicellata

- $\quad$ Leaf bases attenuate to narrowly cuneate; pedicels with both glandular capitate and eglandular trichomes ubiquitous, eglandular trichomes to $0.07 \mathrm{~mm}$ long; corolla green, lobes 4.9-5.5 mm long; Figs. 1B, 2B, 3B

Matelea hildegardiana

3 Corolla purplish; C(is) not distinctly raised off the corolla surface by a subtending stipe; Figs. 1C, 2C 
- $\quad$ Corolla green, greenish-yellow, yellow, or cream; C(is) distinctly raised off the corolla surface by a subtending stipe ............................................4 Open flowers per inflorescence usually 1(-2); peduncles 1.9-10.0 (-16.0) mm [avg. $7 \mathrm{~mm}$ ]; calyx green, sometimes purplish; stipe subtending C(is) $0.12-0.22$ mm [avg. $0.17 \mathrm{~mm}$ ] tall; Figs. 1D, 2D, 3C, 4A, 5........ Matelea brevistipitata - Open flowers per inflorescence usually (2-) 3-4 (-5); peduncles (4-) 8-26 $\mathrm{mm}$ [avg. $15 \mathrm{~mm}$ ]; calyx frequently purple, sometimes black or brown; stipe subtending C(is) $0.3-0.55 \mathrm{~mm}$ tall [avg. $0.37 \mathrm{~mm}$ ]; Figs. 1E \& F, 2 E \& F, $3 \mathrm{D}$

Matelea stenopetala

\section{Matelea brevistipitata Krings \& Morillo, sp. nov.}

urn:lsid:ipni.org:names:77122392-1

http://species-id.net/wiki/Matelea_brevistipitata

Figures 1D, 2D, 3C, 4A, 5

A new species in the Matelea stenopetala complex, most similar to M. stenopetala, but differing in part by inflorescences with fewer flowers open at a time (usually 1(-2) vs. (2-) 3-4 (-5) in M. stenopetala), shorter peduncles (avg. $7 \mathrm{~mm}$ vs. avg. $15 \mathrm{~mm}$ in M. stenopetala), and stipe subtending the C(is) $0.12-0.22 \mathrm{~mm}$ [avg. $0.17 \mathrm{~mm}$ ] tall (vs. 0.3-0.55 $\mathrm{mm}$ tall [avg. $0.37 \mathrm{~mm}$ ] in M. stenopetala].

Type. VENEZUELA. BOLÍVAR: Cerro Guaiquinima, Base Camp (Camp 7) along the Río Canapo, tropical lowland evergreen forest, near river, $5^{\circ} \mathrm{N}, 63^{\circ} \mathrm{W}, 310 \mathrm{~m}, 3 \mathrm{Feb}$ 1990 (fl), B. Boom 9318 (Holotype: VEN!; Isotype: NY!).

Description. Slender, woody vine. Stems glabrescent to moderately pubescent, pubescence in two lines, eglandular trichomes retrorse or spreading, of different size classes, largest ca. $0.5 \mathrm{~mm}$ long, smallest ca. $0.08 \mathrm{~mm}$ long, glandular capitate trichomes sparse to moderately dense, spreading, ca. $0.1 \mathrm{~mm}$ long. Leaf blades lanceolate, ovate, elliptic, oblong, obovate, or oblanceolate, $5.2-11.5 \times 1.1-5.2 \mathrm{~cm}$, with 5-7 pairs of lateral veins, adaxial surface glabrous, midvein glabrous to moderately pubescent, eglandular trichomes spreading, ca. $0.3 \mathrm{~mm}$ long, glandular capitate trichomes spreading, ca. $0.1 \mathrm{~mm}$ long, abaxial surface glabrous, midvein glabrous or sparsely pubescent, eglandular trichomes spreading, ca. $0.3 \mathrm{~mm}$ long, glandular capitate trichomes spreading, ca. $0.1 \mathrm{~mm}$ long, apices acuminate, bases cuneate to rounded, margins entire, colleters 3-4, lanceolate, $0.4-0.6 \mathrm{~mm}$ long; petioles $0.7-3.0 \mathrm{~cm}$ long, moderately pubescent, eglandular trichomes ubiquitous but most dense along adaxial ridge, spreading to antrorse, $0.4-0.5 \mathrm{~mm}$ long, glandular capitate trichomes ubiquitous, spreading, ca. $0.05 \mathrm{~mm}$ long. Inflorescence racemiform, 3-5-flowered (1(-2) flowers open at a time); peduncles 1.9-10 (-16) mm, sparsely to moderately pubescent, pubescence ubiquitous, eglandular trichomes rare, spreading or antrorse, ca. $0.2-0.25 \mathrm{~mm}$ long, glandular capitate trichomes spreading, ca. $0.1 \mathrm{~mm}$ long; pedicels $6.3-15.0 \mathrm{~mm}$ long, sparsely to moderately pubescent, pubescence ubiquitous, eglandular trichomes rare, 

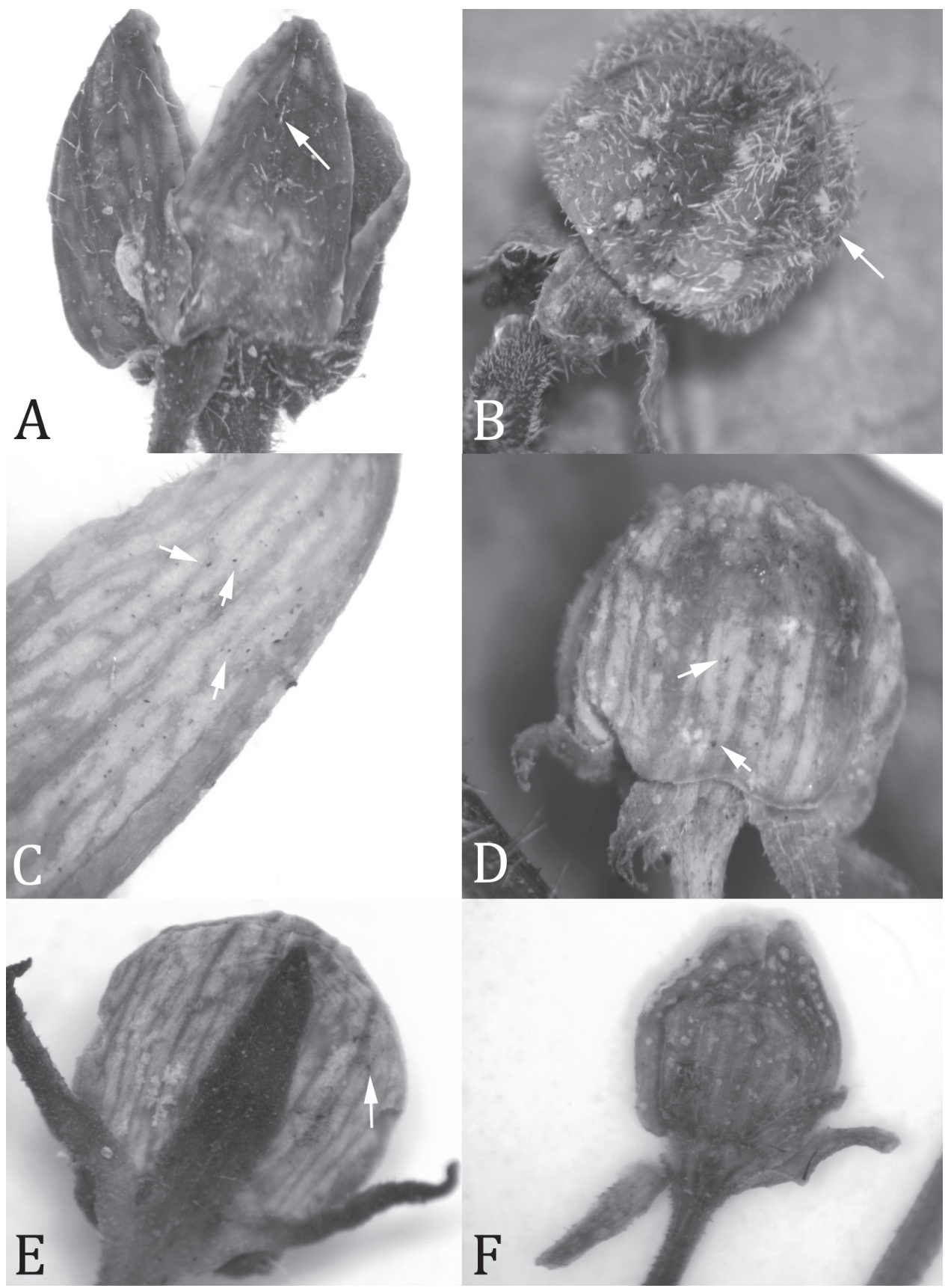

Figure I. Abaxial corolla surface in the adaxially-pubescent-flowered members of the Matelea stenopetala complex. A M. trichopedicellata (based on Daly et al. 1619, US) B M. hildegardiana (based on Liesner 23469, U) C M. pakaraimensis (based on Mutchnik 122, US) D M. brevistipitata (based on Boom 9318, VEN) E Matelea stenopetala (based on Ek et al. 881, U) F M. stenopetala (based on Mori et al. 24547, US); Note difference in pubescence type between $\mathbf{A}-\mathbf{B}$ (eglandular trichomes shown at arrows) and $\mathbf{C}-\mathbf{F}$ (glandular capitate trichomes shown at arrows). 

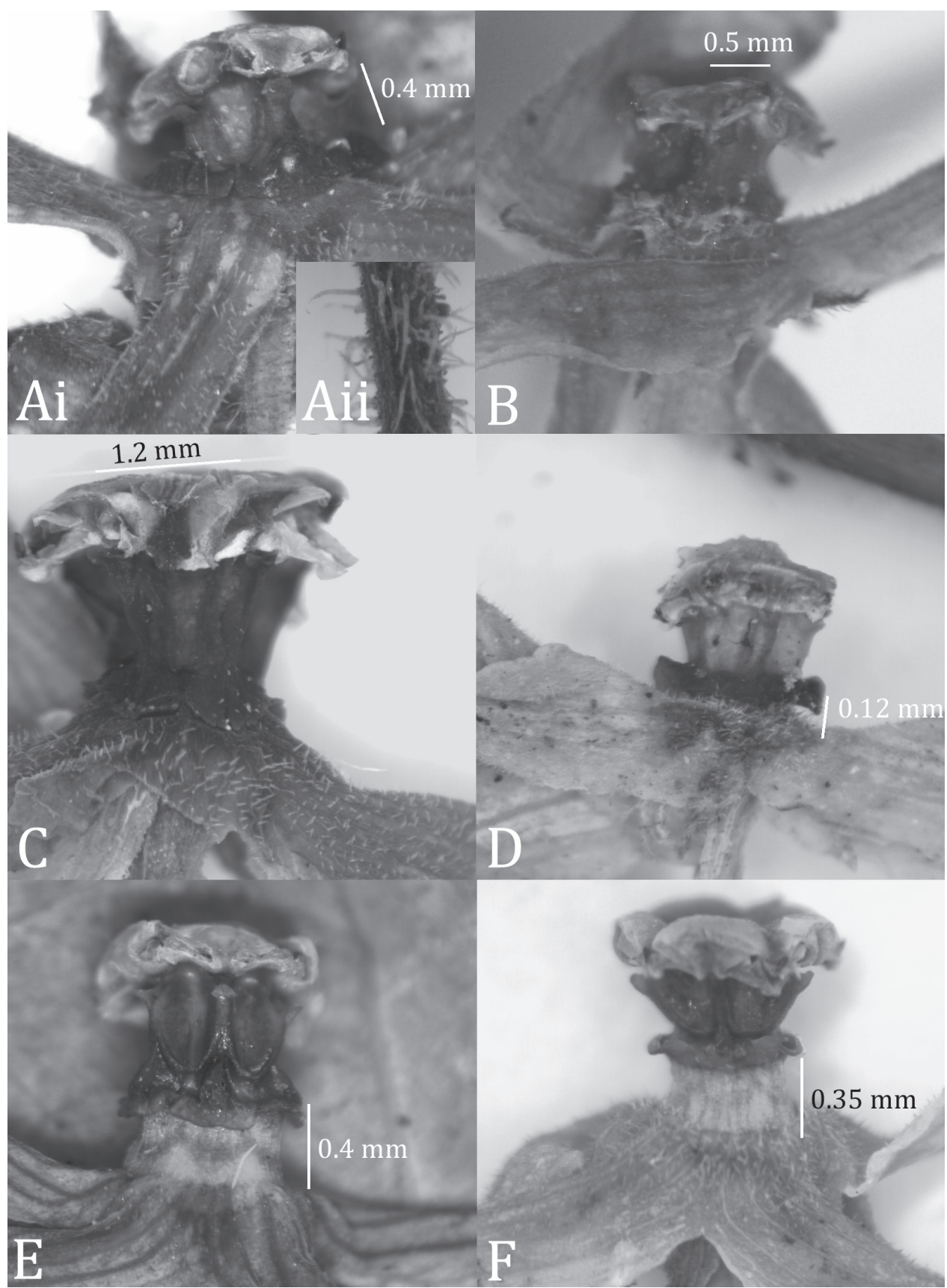

Figure 2. Gynostegial variation in the adaxially-pubescent-flowered members of the Matelea stenopetala complex. A M. trichopedicellata: i, flower, ii, coarsely pubescent pedicel, trichomes ca. $0.3 \mathrm{~mm}$ long (based on Daly et al. 1619, US) B M. hildegardiana (based on Davidse 4903, U) C M. pakaraimensis (based on Mutchnik 122, US) D M. brevistipitata (based on Boom 9318, VEN) E Matelea stenopetala (based on Ek et al. 881, U) F M. stenopetala (based on Mori et al. 24547, US). Note coronas at base of gynostegial columns sessile in A-C and raised off the surface of the corolla by a subtending stipe in D-F. 


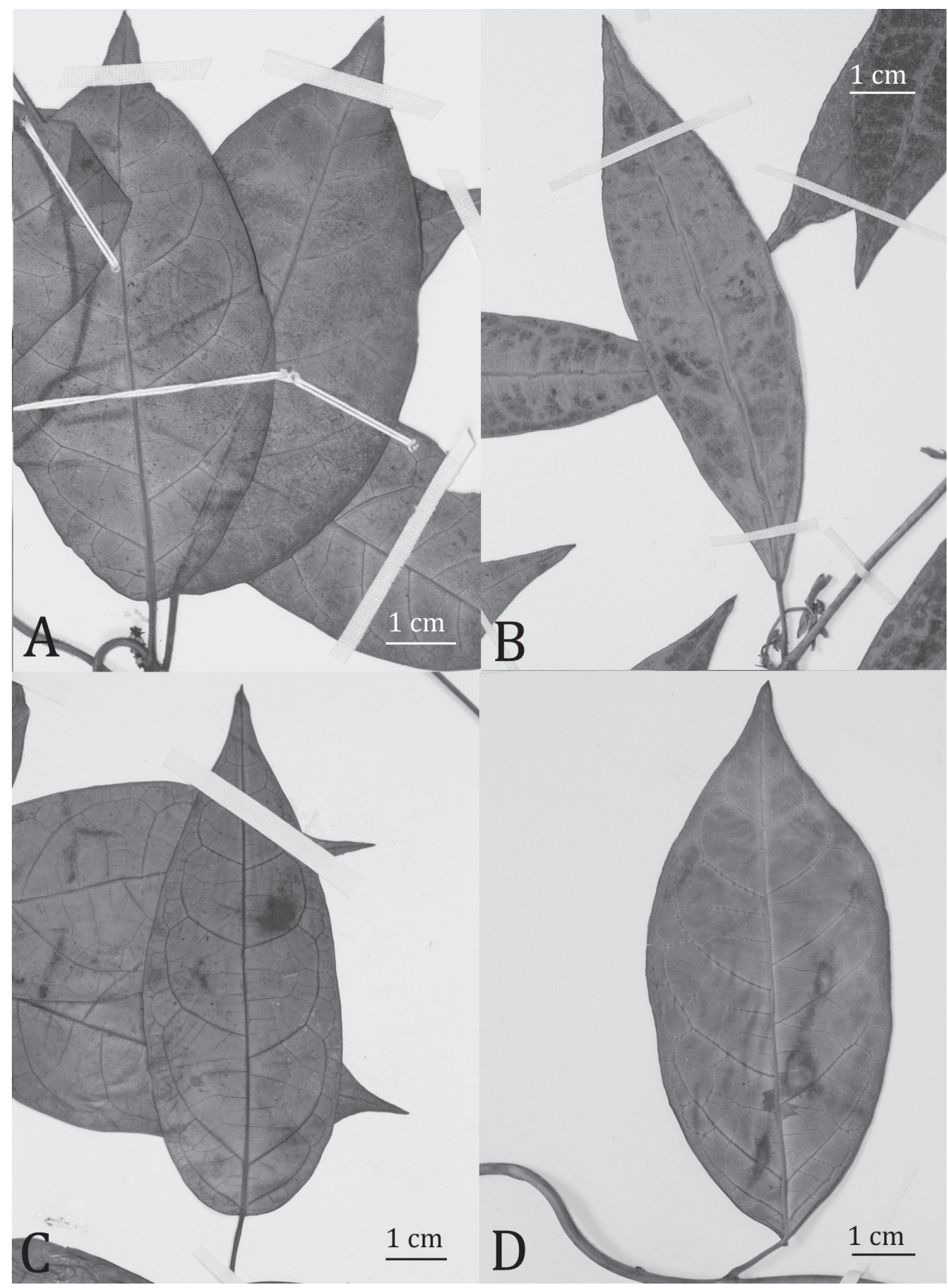

Figure 3. Foliar variation in some adaxially-pubescent-flowered members of the Matelea stenopetala complex. A $M$. trichopedicellata (based on Daly et al. 1619, US) B M. hildegardiana (based on Davidse 4903, US) C M. brevistipitata (based on Boom 9318, VEN) D Matelea stenopetala (based on Ek et al. 881, U). 


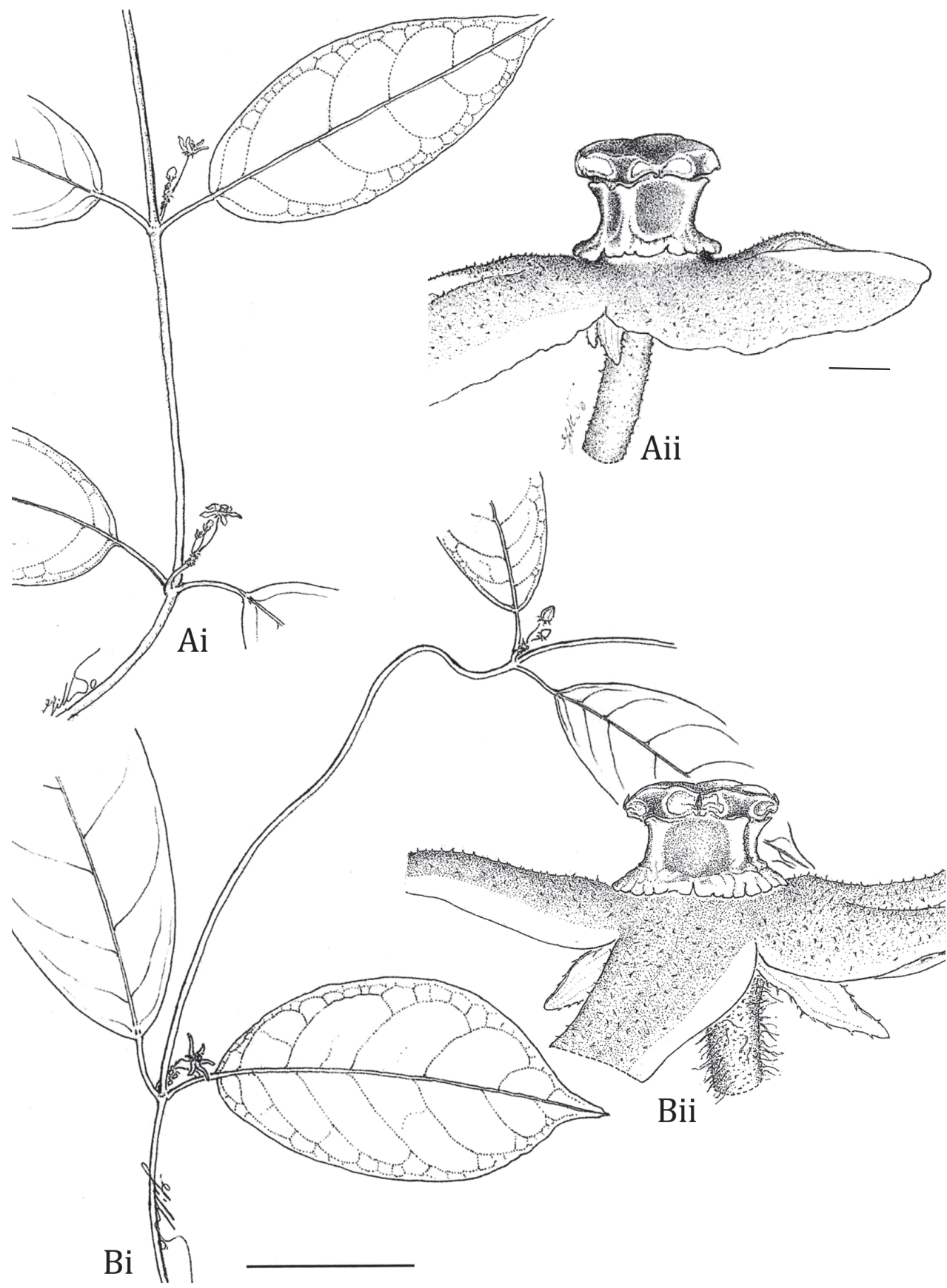

Figure 4. Illustration of the leaves, inflorescences, and flowers of Matelea brevistipitata and M. trichopedicellata. A M. brevistipitata (based on B. Stergios 12315, NY) B M. trichopedicellata (based on Daly et al. 1619, US). Scale bars are $4 \mathrm{~cm}$ (Ai \& Bi) and $0.4 \mathrm{~mm}$ (Aii \& Bii). 


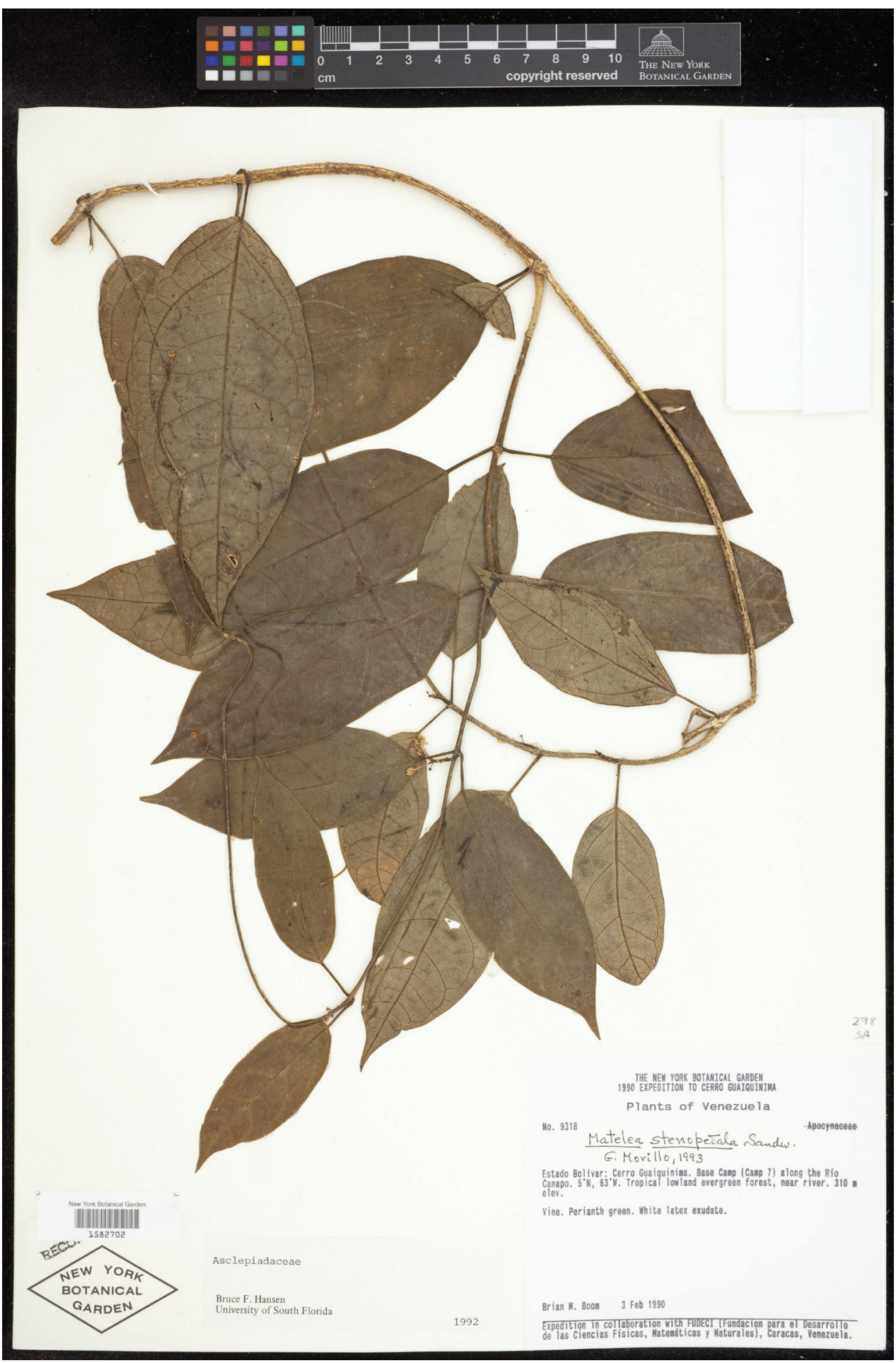

Figure 5. Isotype of Matelea brevistipitata (Boom 9318, NY). Courtesy of the New York Botanical Garden. 
spreading or antrorse, ca. $0.1 \mathrm{~mm}$ long, glandular capitate trichomes spreading, ca. $0.05 \mathrm{~mm}$ long. Calyx lobes linear to lanceolate, $1.1-2.0 \times 0.25-0.45 \mathrm{~mm}$, strongly reflexed, adaxial surface glabrous, abaxial surface sparsely to moderately pubescent, eglandular trichomes spreading or antrorse, ca. $0.3 \mathrm{~mm}$, glandular capitate trichomes spreading, 0.03-0.05 mm long, apices obtuse, margins entire; colleters 1 per sinus, lanceolate, ca. $0.2 \mathrm{~mm}$ tall. Corolla green, greenish-yellow, or greenish-white (fide collectoris), subcampanulate at base, tube ca. 0.5-0.7 $\times 0.8-0.9 \mathrm{~mm}$, lobes imbricate in bud, lanceolate to oblong, apparently spreading, 3.0-4.1 × 1.7-1.9 (-2.2) $\mathrm{mm}$, not ocellate, adaxial surface pubescent, eglandular trichomes spreading, ca. $0.05-0.1 \mathrm{~mm}$ long, glandular-capitate trichomes absent, abaxial surface sparsely pubescent, eglandular trichomes rare, ca. $0.07 \mathrm{~mm}$ long, glandular capitate trichomes spreading, ca. 0.03 $\mathrm{mm}$ long, apices obtuse, margins entire. Faucal annulus (corolline corona or $\mathrm{Ca}$ ) absent. Gynostegial corona of fused staminal (Cs) and interstaminal (Ci) parts, C(is) subtended by a short stipe, stipe $0.12-0.22 \mathrm{~mm}$ tall, Cs rising to meet the lower portion of the anther, rising segment at a distinctly acute angle relative to the base, 0.6-0.66 $\mathrm{mm}$ tall, margin entire, base somewhat swollen, entire or crenulate-lobate, ligule an apical ridge, not free, Ci unlobed, not ligulate. Style-head 1.2-1.4 (-1.7) mm diam, stipe 0.9-1.1 mm tall (incl. section subtending the $\mathrm{C}($ is)), terminal style-head appendage absent. Pollinarium: corpuscula ca. $0.12-0.17 \mathrm{~mm}$ long, caudicles present, pollinia oblong, $0.36-0.4 \times 0.15-0.25 \mathrm{~mm}$. Follicles unknown. Seeds unknown.

Distribution. Matelea brevistipitata is apparently endemic to the Guiana Shield in the Venezuelan states of Amazonas and Bolívar. It is very likely also present in the portion of Amazonian Brazil bordering those states. The distributions of $M$. brevistipitata and $M$. stenopetala appear to be largely parapatric. Both species occur in Bolívar (Venezuela), but this represents the easternmost edge of the range of $M$. brevistipitata and the westernmost edge of the range of $M$. stenopetala.

Ecology. Known from swamp and riverine forests at low elevations, to $500 \mathrm{~m}$.

Phenology. Collected in flower in April, May, October, and November.

Etymology. The specific epithet refers to the short stipe subtending the $\mathrm{C}(\mathrm{is})$.

Conservation status. Currently, very little is known regarding the status of this species.

Discussion. At a glance, Matelea brevistipitata can be distinguished from $M$. stenopetala by the few-flowered inflorescences, suggesting divergence in reproductive biology. Matelea stenopetala usually displays inflorescences with 3-4 open flowers, whereas $M$. brevistipitata displays inflorescences with only one open flower (rarely two) at a time. The floral display itself also differs between the two species. Although both exhibit calyx lobes strongly reflexed at anthesis, the lobes of $M$. stenopetala tend to be purple (sometimes also black or brown), presenting a striking contrast to the light colored corolla. In $M$. brevistipitata, in contrast, the calyx is usually green (frequently drying an olive green). While the adaxial corolla surface is pubescent in $M$. brevistipitata, it is only very rarely so in $M$. stenopetala. In fact, the vast majority of specimens of $M$. stenopetala seen exhibit corollas adaxially glabrous. It is worth noting that the rare exception (i.e., Mori 24547, US) otherwise exhibits character states typical of $M$. stenopetala, including long peduncles $(13-16 \mathrm{~mm})$, 
inflorescences with up to five flowers open at a time, and long stipes subtending the C(is) (0.35 mm; Fig. 2F).

Specimens examined. Venezuela: Amazonas. Camino entre caño Gruya y el pueblo de Gruya, bosque higrófilo macrotérmico ligeramente alterado en la margen del río Orinoco, 100 m, 8 Apr 1978 (f), G. Morillo 7382 (VEN); Dept. Atabapo, Salto Yureba, Caño Yureba, Bajo Ventuari, $4^{\circ} 3^{\prime} \mathrm{N}, 6^{\circ} 1^{\prime} \mathrm{W}, 120-150$ m, 24 Oct-4 Nov 1981 (fl), F. Delascio \& F. Guánchez 10968 (MER,VEN); Dept. Atures, carretera Pto. Ayachucho-Samariapo, selva húmeda caliente, 13 Jan 1982 (fl), B. Stergios 3183 (VEN); Dept. Río Negro, between Río Marawinuma at base of Neblina $\left(0^{\circ} 50^{\prime} \mathrm{N}\right.$, $\left.66^{\circ} 9^{\prime} \mathrm{W}\right)$ and Río Baría, in swamp forest, a heavily overgrown series of small channels with black water, 8 May 1984 (f), W.W. Thomas, A. Gentry \& B. Stein 3401 (VEN, NY). Bolívar. Dept. Roscio, El Abismo, al norte del río Icabarú, bosque húmedo macrotérmico, 500 m, Oct 1985 (fl), F. Delascio 12503 (VEN); Expedición Proyecto I.R.N.R.S. a la cuenca alta del Río Caura (Hoja NB-20-14), selvas ribereñas del Caño El Pavo hasta arriba de la boca del Caño Maravene, 4 $16^{\prime} \mathrm{N}, 64^{\circ} 9^{\prime} \mathrm{W}, 13-14$ Apr 1988 (f), B. Stergios 12315 (NY, US, VEN); Dist. Piar, Río Aparamán, at rapids of Yuraymerú, tributary of Río Acanan, SW base of Amaruay-tepui, E of Auyan-tepui, W of Aparaman-tepui, small tributary or river, densely forested with trees 20-30 m high, 55 'N, 62¹5'W, 500 m, 21 Apr 1986 (f), B. Holst \& R. Liesner 2661 (VEN, MO).

\section{Matelea trichopedicellata Krings \& Morillo, sp. nov.}

urn:lsid:ipni.org:names:77122393-1

http://species-id.net/wiki/Matelea_trichopedicellata

Figures 1A, 2A, 3A, 4B, 6

A new species in the Matelea stenopetala complex, most similar to M. hildegardiana, but differing in part by leaf bases broadly cuneate to rounded (vs. attenuate to narrowly cuneate in M. hildegardiana), pedicels coarsely pubescent, with only glandular capitate trichomes ubiquitous, eglandular trichomes not ubiquitous, rather in two lines, ca. $0.3 \mathrm{~mm}$ long (vs. both glandular capitate and eglandular trichomes ubiquitous, eglandular trichomes to 0.07 mm long in M. hildegardiana), and corollas rose, lobes 4.1-4.2 mm long (vs. corolla green, lobes 4.9-5.5 mm long in $M$. hildegardiana).

Type. BRAZIL. PARÁ: Rio Tocantins near Igarapé Cajazeirinha, approx. $30 \mathrm{~km} \mathrm{~N}$ of Itupiranga, $4^{\circ} 1^{\prime} \mathrm{S}, 49^{\circ} 21 \mathrm{~W}, 1 \mathrm{Dec} 1981$ (f \& fr), D.C. Daly, R. Callejas, M.G. da Silva, E.L. Taylor, C. Rosario, \& M.R. dos Santos 1619 (Holotype: NY!; Isotype: US!, MG, n.v., MO, n.v.).

Description. Slender, woody vine. Stems moderately to densely pubescent, pubescence in two lines, eglandular trichomes coarse, retrorse, ca. $0.4 \mathrm{~mm}$ long, glandular capitate trichomes sparse, spreading, ca. $0.05 \mathrm{~mm}$ long. Leaf blades narrowly to broadly elliptic, $5.7-7.8 \times 2.0-4.5 \mathrm{~cm}$, with $5-8$ pairs of lateral veins, adaxial surface 


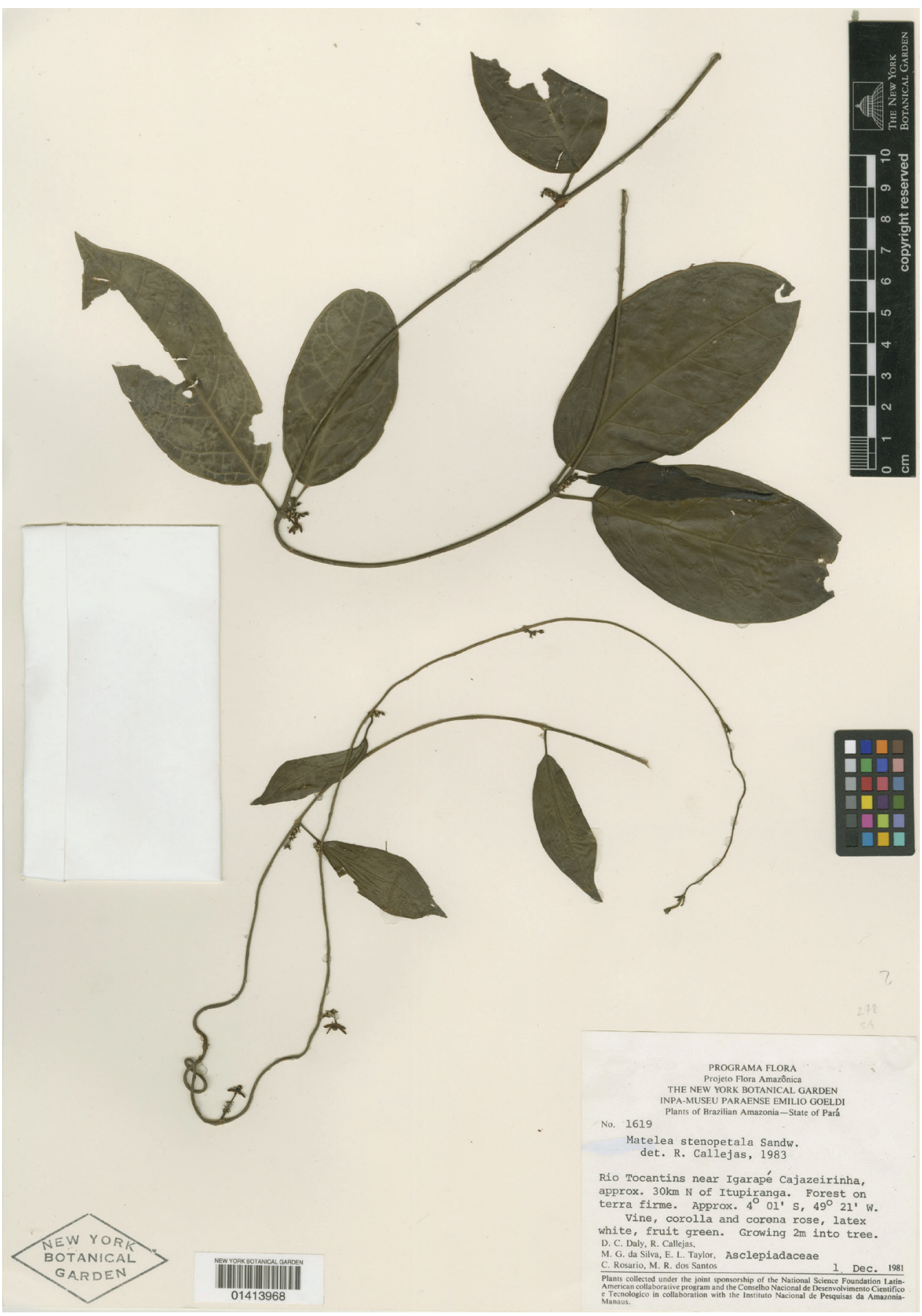

Figure 6. Holotype of Matelea trichopedicellata (Daly et al. 1619, NY). Courtesy of the New York Botanical Garden. 
glabrous, midvein glabrous or pubescent, eglandular trichomes antrorse or spreading, ca. $0.3 \mathrm{~mm}$ long, glandular capitate trichomes spreading, ca. $0.05-0.07 \mathrm{~mm}$ long, abaxial surface glabrous, midvein glabrous or pubescent, eglandular trichomes antrorse or spreading, ca. $0.3 \mathrm{~mm}$ long, glandular capitate trichomes spreading, ca. 0.05$0.07 \mathrm{~mm}$ long, apices acuminate, bases broadly cuneate to rounded, margins entire, colleters $2-4$, lanceolate, $0.3-0.4 \mathrm{~mm}$ long; petioles $0.9-1.3 \mathrm{~cm}$ long, moderately pubescent, pubescence ubiquitous, eglandular trichomes mostly restricted to the adaxial ridge, spreading to antrorse-spreading, ca. $0.4 \mathrm{~mm}$ long, glandular capitate trichomes spreading, 0.05-0.07 mm long. Inflorescence racemiform, apparently 1-2-flowered (1 flower open at a time); peduncles to $2.4 \mathrm{~mm}$ long, moderately pubescent, pubescence ubiquitous, eglandular trichomes antrorse or spreading, $0.2-0.25 \mathrm{~mm}$ long, glandular capitate trichomes spreading, $0.05-0.07 \mathrm{~mm}$ long; pedicels $4.4-5.2 \mathrm{~mm}$ long, moderately to densely pubescent, eglandular trichomes in two lines, spreading, ca. $0.3 \mathrm{~mm}$ long, glandular capitate trichomes ubiquitous, spreading, ca. 0.05-0.07 mm long. $\mathrm{Ca}$ lyx lobes lanceolate, reflexed or spreading, 1.4-1.7 $\times 0.4-0.6 \mathrm{~mm}$, adaxial surface glabrous, abaxial surface moderately to densely pubescent, eglandular trichomes antrorse or spreading, ca. $0.18 \mathrm{~mm}$ long, glandular capitate trichomes absent or very sparse, spreading when present, ca. $0.06 \mathrm{~mm}$ long, apices obtuse, margins entire; colleters 1 per sinus, lanceolate, ca. $0.18 \mathrm{~mm}$ tall. Corolla rose (fide collectoris), subcampanulate at base, tube ca. $0.9 \times 0.9 \mathrm{~mm}$, lobes imbricate in bud, linear-lanceolate to oblong, spreading, $4.1-4.2 \times 1.9-2.0 \mathrm{~mm}$, not ocellate, marginally or laterally recurved, adaxial surface pubescent, eglandular trichomes spreading, ca. $0.06-0.08 \mathrm{~mm}$ long, glandular-capitate trichomes absent, abaxial surface moderately pubescent, eglandular trichomes antrorse, $0.15-0.18 \mathrm{~mm}$ long, glandular capitate trichomes absent or very sparse, spreading when present, $0.03-0.04 \mathrm{~mm}$ long, apices obtuse, margins entire. Faucal annulus (corolline corona or $\mathrm{Ca}$ ) absent. Gynostegial corona of fused staminal (Cs) and interstaminal (Ci) parts, $\mathrm{C}(\mathrm{is})$ on the surface of the corolla lobes, not subtended by a stipe, margin crenulate-lobate, Cs rising to meet the lower portion of the anther, rising segment more or less perpendicular relative to the base, ca. $0.4 \mathrm{~mm}$ tall, margin entire, base somewhat swollen, crenulate-lobate, ligule an apical ridge, not free, $\mathrm{Ci}$ unlobed, not ligulate. Style-head 1.6-1.7 mm diam, stipe 0.45-0.65 mm tall, terminal style-head appendage absent. Pollinarium: corpuscula ca. $0.18 \mathrm{~mm}$ long, caudicles present, pollinia narrowly ovoid, ca. $0.45 \times 0.2 \mathrm{~mm}$. Follicles ovoid-fusiform (imm), ca. 6 × $1.3 \mathrm{~cm}$. Seeds unknown.

Distribution. Known only from the type, collected in the Brazilian Amazon, near Igarapé Cajazeirinha.

Ecology. Currently known only from terra firme forest.

Phenology. Collected in flower and fruit (imm) in December.

Etymology. The specific epithet refers to the conspicuously pubescent pedicels.

Conservation status. Currently, very little is known regarding the status of this species.

Discussion. Matelea trichopedicellata shares with $M$. hildegardiana (apparently endemic to the Gran Sabana, Bolívar, Venezuela), pubescent abaxial and adaxial corolla surfaces, but differs from it in part by leaf bases broadly cuneate to rounded and corolla 
lobes rose, 4.1-4.2 $\mathrm{mm}$ long (leaf bases attenuate to narrowly cuneate, and corolla lobes green, 4.9-5.5 mm long in $M$. hildegardiana). Matelea trichopedicellata and $M$. hildegardiana both exhibit eglandular trichomes on the abaxial corolla lobe surface in which the lowest cell is usually filled with a green or dark substance. The upper cells of the trichomes are usually translucent.

\section{Acknowledgments}

We thank the following herbaria for providing specimen loans pertinent to this study: NY, U, US, and VEN. We also thank the kind staff of NY, US and VEN for their hospitality during our recent visits, and particularly Brian Boom, Doug Daly, Lucy Klebieko, and Edgardo Rivera for arranging scans of type specimens at NY.

\section{References}

Endress ME, Bruyns PV (2000) A revised classification of the Apocynaceae, s.l. Botanical Review 66: 1-56. doi: 10.1007/BF02857781

Farinaccio MA, Stevens WD (2009) Matelea quindecimlobata (Apocynaceae, Asclepiadoideae), a new species from Amazonas, Brazil. Novon 19(2): 156-158. doi: 10.3417/2007134

Krings A (2011) Matelea pakaraimensis (Apocynaceae, Asclepiadoideae), a new species in the Matelea stenopetala complex from Guyana. Journal of the Botanical Research Institute of Texas 5: 101-104.

Liede S, Kunze H (1993) A descriptive system for corona analysis in Asclepiadaceae and Periplocaceae. Plant Systematics and Evolution 185: 275-284. doi: 10.1007/BF00937663

Livshultz T (2003) Systematics of Dischidia (Apocynaceae, Asclepiadoideae). Ph.D. Thesis, Cornell University, USA.

Morillo G (1988) Especies, combinaciones y sinonimos nuevos en Fischeria DC., Gonolobus Mich. y Matelea Aubl. Commentarios sobre una especia interesante de Gonolobus Mich. y sus afines. Ernstia 50: 12-31.

Morillo G (1991) Once Asclepiadaceae sudamericanas nuevas para la ciencia. Ernstia 1(3): $109-120$.

Sandwith NY (1931) Contributions to the flora of tropical America: VIII. Bulletin of Miscellaneous Information Kew 1931: 467-492. doi: 10.2307/4102561 